\title{
Orexin Receptor Antagonism: A New Principle in Neuroscience
}

\author{
Christoph Boss*, Catherine Brisbare-Roch*, Francois Jenck, Hamed Aissaoui, Ralf Koberstein, \\ Thierry Sifferlen, and Thomas Weller
}

\begin{abstract}
Orexins are hypothalamic neuropeptides interacting with G-protein coupled receptors in the brain. They play a role in the regulation of sleep-wake cycles in mammals, as suggested by the deficits in orexinergic function that are associated with rodent, canine and human narcolepsy. Selective or dual orexin1-receptor and/or orexin2receptor antagonists or agonists that cross the blood-brain-barrier (BBB) may be of therapeutic interest for disorders of disturbed arousal and alertness. This article summarizes recent research to identify and characterize orexin receptor antagonists and their therapeutic potential for normalizing sleep in insomnia patients.
\end{abstract}

Keywords: G-protein coupled receptors · Medicinal chemistry · Neuroscience · Orexin receptor antagonists · Sleep-wake cycle

\section{Introduction and Biological Background}

Orexins (orexin A and orexin B, also named hypocretin 1 and 2, respectively) are peptides discovered in the brain in 1998 by two independent research groups as the result of systematic and intensive research programs on orphan G-protein-coupled receptors. ${ }^{[1,2]}$ Orexins bind to two receptors (orexin1/ $\mathrm{OX}_{1}$ and orexin $2 / \mathrm{OX}_{2}$ receptors, also named HCRT1 and HCRT2 receptors, respectively) and are proteolytically derived from a single precursor peptide in a discrete population of neurons of the lateral hypothalamus. $\mathrm{OX}_{1}$ receptors have preferential affinity for orexin $\mathrm{A}$ whereas $\mathrm{OX}_{2}$ receptors

${ }^{*}$ Correspondence: Dr. C. Boss, Dr. C. Brisbare-Roch Actelion Pharmaceuticals Ltd

Drug Discovery and Preclinical Research \& Development

Gewerbestrasse 16

$\mathrm{CH}-4123$ Allschwil / BL

Tel.: +41615656561

Fax: +41615656500

E-mail: christoph.boss@actelion.com

E-mail: catherine.brisbare@actelion.com do not discriminate between both neuropeptides in vitro. $\mathrm{OX}_{1}$ or $\mathrm{OX}_{2}$ activation produces intracellular $\mathrm{Ca}^{2+}$ increases via functional coupling involving a $\mathrm{Gq}$ mechanism of transduction. ${ }^{[3]}$ This ultimately results in slow membrane depolarization and in neuronal activation found to involve different ionic conductances in various brain regions in the rat, such as potassium conductance in locus coeruleus ${ }^{[4]}$ or calcium current in tuberomammilary nucleus. ${ }^{[5]}$

The orexin system is well conserved across mammalian species. Orexin A is similar in rat, mouse, pig, and man and contains two disulfide bridges. Orexin B in rat and mouse differs by only one amino-acid (S18N) from porcine and human orexin $\mathrm{B}$; it is a linear, non-lipophilic, less stable peptide than orexin A. Both orexins are derived from a single precursor peptide coded on human chromosome 17q21-24, which is syntenic with mouse chromosome 11.6] High structural and functional homology is also reported for rat and human $\mathrm{OX}_{2}$ and $\mathrm{OX}_{1}$ receptors. The in vitro pharmacology of human and rat orthologs of $\mathrm{OX}_{1}$ is very similar. ${ }^{[7]}$ The human $\mathrm{OX}_{1}$ receptor is coded on chromosome $1 \mathrm{p} 33$ and contains seven exons, the human $\mathrm{OX}_{2}$ receptor is coded on chromosome 6p11-q11 containing seven exons over 108439 base pairs. In the mouse, splice variants of $\mathrm{OX}_{2}$ are distributed in a tissue-specific manner. ${ }^{[8]}$

Following original observations that orexins have a role in appetite and food intake, most recent evidence suggests that orexins play a determinant role in functions beside the regulation of appetite. Orexins may thus be important in food intake only under particular circumstances, e.g. in response to hypoglycemia and/or in the regulation of circadian food intake. ${ }^{[9]}$ Nerve fibers from orexin neurons are widely distributed in the brain suggesting that orexins exert multiple functions, in particular as regulators of behavioral arousal, sleep and wake states. Indeed, hypothalamic neurons have dense projections ${ }^{[10]}$ to the basal forebrain, limbic structures and brainstem regions, in particular those related to waking and rapid eye movement (REM) sleep regulation. Enhanced behavioral activity, increased attention, prolonged latency to the first occurrence of REM, maintenance of cortical activation and activated cell firing in thalamic or reticular regions such as the locus coeruleus have been consistently reported following intracerebroventricular (icv) infusion of orexins in the rat. ${ }^{[1,12]}$

Since many homeostatic processes in mammals (e.g. food intake, body temperature, hormone release) are intimately linked to sleep and arousal, it is likely that orexins link sleep and arousal to these processes. It remains to study the orexin circuitry that is disturbed under states such as sleep loss, night or shift work, jet lag, aging, affective disorders and endocrine diseases. Manipulation of the orexin peptide-receptor system using brain-penetrant orexin receptor antagonists or full, partial, or inverse agonists may prove therapeutically useful in the treatment of those medical and psychiatric conditions associated with sleep disturbances. The relative brain distribution of $\mathrm{OX}_{1}$ versus $\mathrm{OX}_{2}$ receptors and their 
contribution to diverse neurobiological effects implies that different biological effects might be expected from drugs acting in the brain selectively at either $\mathrm{OX}_{1}$ or $\mathrm{OX}_{2}$ receptors or both.

\section{Synthetic Orexin Receptor Ligands: Recent Patents on Antagonists}

Several companies are working in the field of orexin receptor antagonism. Analysis of the recent patent literature shows that Merck \& Co, Sanofi-Aventis and Actelion Pharmaceuticals seem to be very active in the field. A literature search going further back shows that GlaxoSmithKline (GSK) was very active in the field until 2004. Since then, no new patents have appeared authored by GSK, claiming orexin receptor antagonists. In the following sections a short summary of the patent literature is given. The authors do not claim completeness.

The patent literature generally implies the importance of orexin receptors to diverse pathologies, the most important being eating and appetite disorders, sleep disorders, depression, anxiety, or addictions. The different disorders seem to have different relationships to the orexin system. For treatment of certain diseases selective orexin receptor antagonists, either $\mathrm{OX}_{1}$ - or $\mathrm{OX}_{2}$-selective compounds might be suitable, as for treatment of other pathologies dual $\mathrm{OX}_{1}-\mathrm{OX}_{2}$-antagonists might be necessary. With clinical investigations of further compounds exhibiting different selectivity profiles, some of the questions about an optimal selectivity profile may be answered.

\subsection{Orexin Receptor Antagonists from Merck \& Co}

A search in the Integrity ${ }^{\circledR}$ database (Prous Science) in the patents section, with the keywords 'Orexin AND Merck' resulted in the following hits, describing compounds from the classes depicted in Fig. 1.

Scientists at Merck \& Co have so far mainly worked on structural classes related to earlier work done at GlaxoSmithKline (see Section 2.4.). The general structure of the majority of Merck's orexin receptor antagonists can be described as consisting of two aromatic systems connected by a linker of three or four bonds in length ( $\mathbf{1}$ to $\mathbf{6})$ Fig 1 . Derivatives $\mathbf{1}$ and 2 are based on a linear chain linker. ${ }^{[13,14]}$ One of the substituents is usually an orthobiphenyl unit or a system which is structurally closely related, e.g. 5-aryl-thiazoles or 2-heteroaryl-phenyl-groups. With respect to the second aryl-unit, the receptors seem to be quite tolerant, as one can find simple phenyl-rings as well as a diversity of bicyclic, fused heteroaromatic systems. With

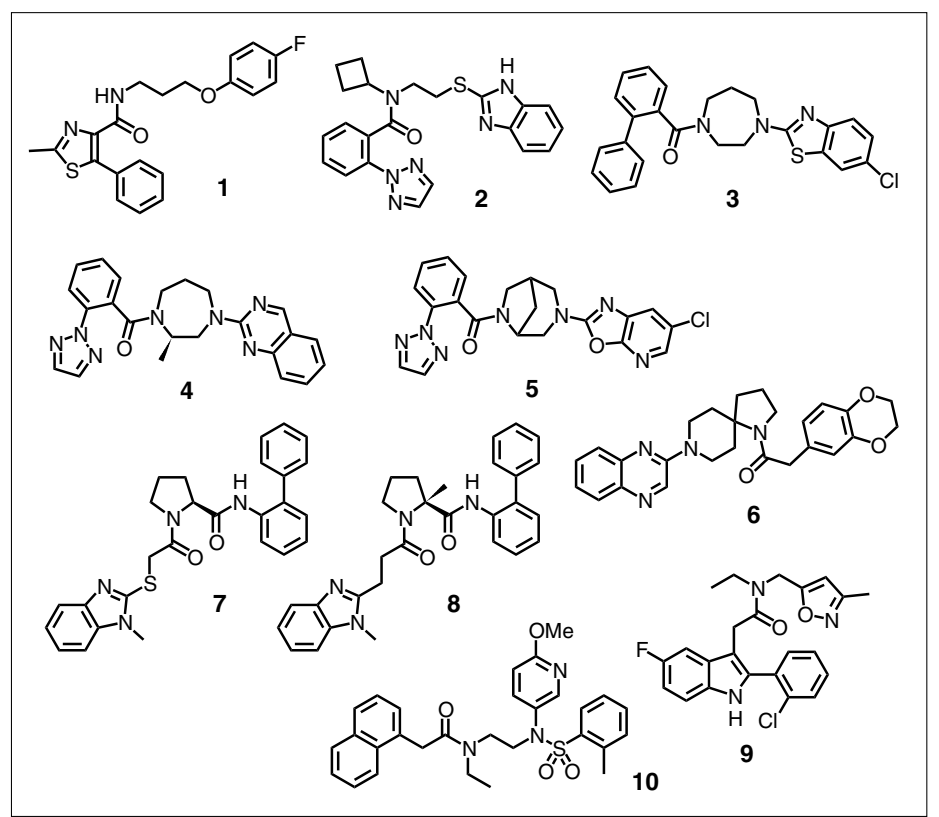

Fig. 1. Structures of orexin receptor antagonists from Merck \& Co

respect to orexin antagonistic activity, no specific statements were made in any of Merck's patents. In general, the compounds inhibit both orexin receptors with an $\mathrm{IC}_{50}$ $<50 \mu \mathrm{M}$. Preferred compounds show an $\mathrm{IC}_{50}<100 \mathrm{nM}$ on at least one of the orexin receptors. Compounds $\mathbf{3 , 4}$, and $\mathbf{5}$ represent examples from very recent patents. They are closely related to $\mathbf{1}$ and $\mathbf{2}$ but contain a diazepan ring system which can additionally be bridged or substituted, linking the two substituents together.[15-17] Depending on which way one follows the path from the first $\mathrm{N}$-atom to the second $\mathrm{N}$-atom, we either have a linker of two or of three atoms. These derivatives can therefore be considered as a combination of $\mathbf{1}$ and $\mathbf{2}$. Derivative $\mathbf{6}$ connects the two aromatic units with a spiro-diamine unit. ${ }^{[18]}$ This type of linkage seems to tolerate a new type of substituents, since the $o$-biaryl residues have been replaced by phenyl acetic acid residues. The proline derivatives $\mathbf{7}$ and $\mathbf{8}$ represent yet another group of dual orexin receptor antagonists. ${ }^{[19,20]}$ The patent literature does not give insight into the activity pattern of this class of compounds, but it seems to be necessary to separate the two aromatic units by a different linker arrangement. A major difference as compared to the former classes of orexin receptor antagonists is the inversion of the amide connecting the $o$-biaryl unit to the template and the addition of a spacer of two bonds between the carbonyl group and the second aryl system. A more detailed picture of these compounds was recently published indicating that 7 has a $\mathrm{K}_{\mathrm{i}}\left(\mathrm{OX}_{1}\right)$ of $3 \mathrm{nM}$ and $\mathrm{a} \mathrm{K}_{\mathrm{i}}\left(\mathrm{OX}_{2}\right)$ of $0.2 \mathrm{nM}$ as well as a suitable pharmacokinetic profile and substantial brain penetration after i.p.-administration to rats. ${ }^{[21]}$ In addition the compounds were assessed for their potential as P-gp-substrates. It could be shown that 7 was only a moderate substrate. In vivo activity of the compounds was assessed in a rat model inducing locomotion by icv injections of ADL-orexin B peptide. It could be shown that pretreatment of rats with a dual orexin receptor antagonist, e.g. 7, could suppress increased locomotor activity of ADL-orexin B challenged rats.

Further structural classes of orexin receptor antagonists developed at Merck are the 2-aryl indole-based compounds represented by 9 and the sulfonamide derivatives exemplified by 10. ${ }^{[22,23]}$

\subsection{Orexin Receptor Antagonists from Actelion Pharmaceuticals Ltd}

A search in the Integrity ${ }^{\circledR}$ database (Prous Science) in the patents section, with the keywords 'Orexin AND Actelion' resulted in the following hits, describing compounds from the classes depicted in Fig. 2. The major efforts in the field of orexin receptor antagonists undertaken at Actelion Pharmaceuticals are mentioned in Section 3 describing the pharmacology of almorexant (11, ACT-078573) which is in phase III clinical development for the treatment of primary insomnia.

Compounds like 12 and $\mathbf{1 3}$ are obviously structurally very closely related to almorexant (11). In 12 the phenyl ring of the phenethyl side chain of almorexant (11) is replaced by a pyridine ring. ${ }^{[24,25]}$ The compound is described to show in vivo activity in electrophysiological measures of sleep parameters (explained below, Section 3) and to have a favourable cytochrome inhibition profile. Compound $\mathbf{1 3}$ is an example of a series of primary amides structurally 

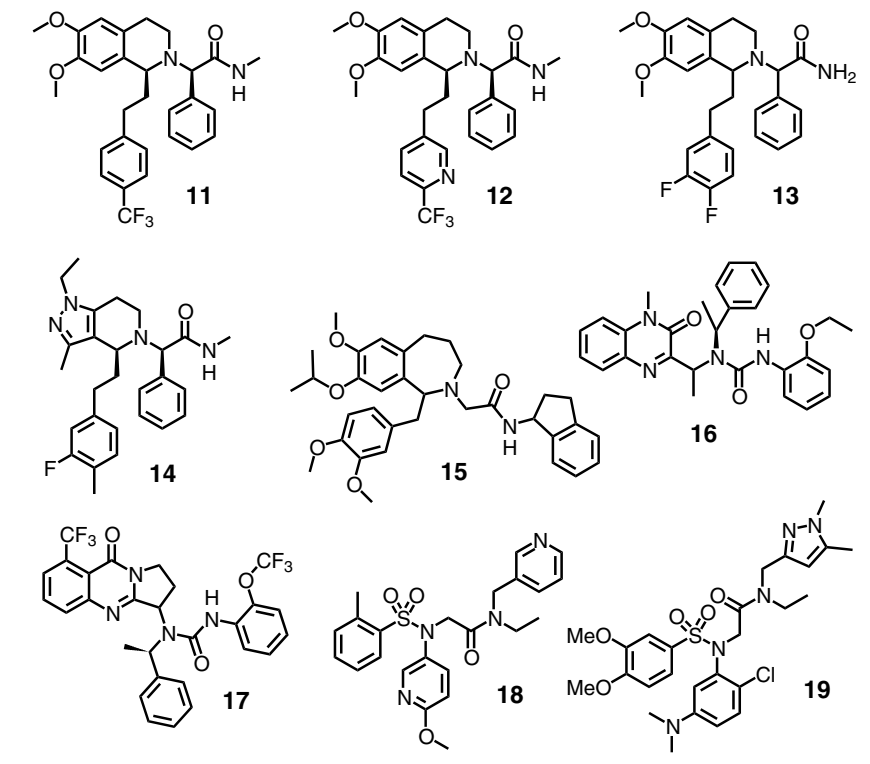

Fig. 2. Structures of orexin receptor antagonists from Actelion Pharmaceuticals Ltd

closely related to almorexant (11). ${ }^{[26]}$ Most examples in this patent are described as being dual orexin receptor antagonists. The patent does not indicate any preferred stereochemistry and as well allows for benzyl substituents as replacements of the phenethyl substituent depicted in 13. In another patent, Actelion Pharmaceuticals describes tetrahydro-pyrazolo-pyridine derivatives as novel orexin receptor antagonists. ${ }^{[27]}$ As an example of this group of orexin receptor antagonists, compound $\mathbf{1 4}$ is given (Example 32 from the patent with an $\mathrm{IC}_{50}\left(\mathrm{OX}_{1}\right)$ $=49 \mathrm{nM}$ and an $\left.\mathrm{IC}_{50}\left(\mathrm{OX}_{2}\right)=2 \mathrm{nM}\right)$. The derivatives related to $\mathbf{1 4}$ are described to be very potent orexin receptor antagonists with a tendency of being more active on the $\mathrm{OX}_{2}$-receptor. Another group of antagonists is represented by the benzazepine derivative 15. ${ }^{[28]}$ The activity of the specific compound (Example 68 from the patent) is given with an $\mathrm{IC}_{50}\left(\mathrm{OX}_{1}\right)$ of $12 \mathrm{nM}$ and an $\mathrm{IC}_{50}\left(\mathrm{OX}_{2}\right)$ of $174 \mathrm{nM}$, respectively. The benzazepine-based group of orexin receptor antagonists, according to the activity table in the patent, seems to represent a class of rather $\mathrm{OX}_{1}$ selective derivatives. Further structurally different classes of compounds are reflected by $\mathbf{1 6}$ (quinoxalin-3-ones) and 17 (quinazolinones).[29,30] Both groups are described as being dual $\mathrm{OX}_{1} / \mathrm{OX}_{2}$ receptor antagonists with activities of $1 \mathrm{nM}<\mathrm{IC}_{50}$ $<100 \mathrm{nM}$ for 16 and $\mathrm{IC}_{50}\left(\mathrm{OX}_{1}\right)=12 \mathrm{nM} /$ $\mathrm{IC}_{50}\left(\mathrm{OX}_{2}\right)=16 \mathrm{nM}$ for 17. A last group of Actelion orexin receptor antagonists are the sulfonamides 18 and 19. ${ }^{[31,32]}$ Compound 18 is a representative of a class of $\mathrm{OX}_{2}$ selective antagonists $\left(\mathrm{IC}_{50}\left(\mathrm{OX}_{1}\right)>10000 \mathrm{nM}\right.$ and $\left.\mathrm{IC}_{50}\left(\mathrm{OX}_{2}\right)=2 \mathrm{nM}\right)$, whereas 19 represents a differently substituted sulfonamide from a class of highly potent dual orexin re-

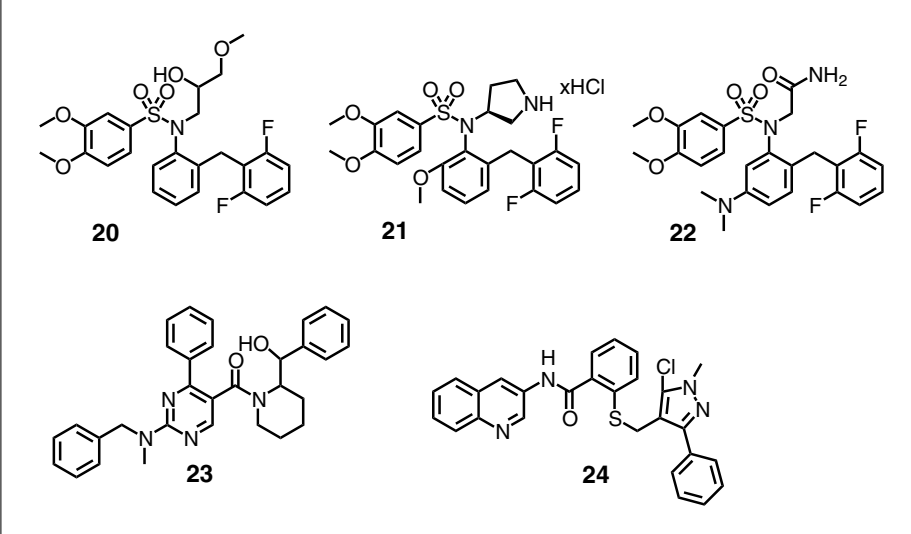

Fig. 3. Structures of orexin receptor antagonists from Sanofi-Aventis

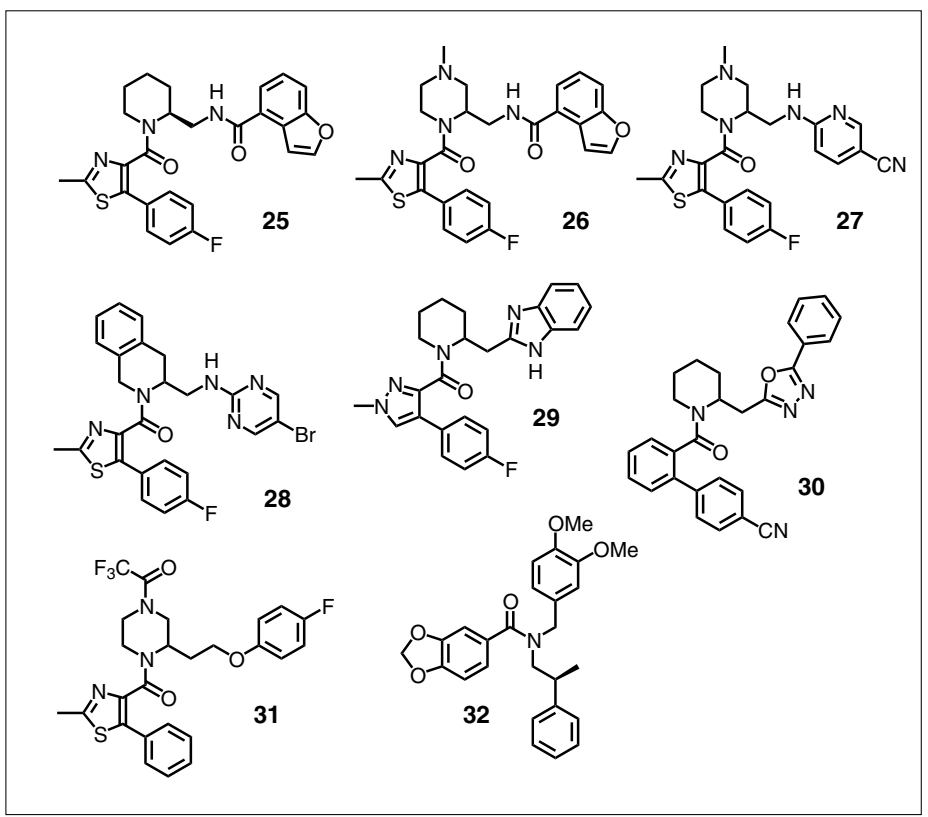

Fig. 4. Structures of orexin receptor antagonists from GlaxoSmithKline

ceptor antagonists $\left(\mathrm{IC}_{50}\left(\mathrm{OX}_{1}\right)=6 \mathrm{nM}\right.$ and $\left.\mathrm{IC}_{50}\left(\mathrm{OX}_{2}\right)=11 \mathrm{nM}\right)$. The selectivity profile seems to depend on the specific substitution pattern of the (hetero)aromatic groups contained in the molecules.

\subsection{Orexin Receptor Antagonists from Sanofi-Aventis}

A search in the Integrity ${ }^{\circledR}$ database (Prous Science) in the patents section, with the keywords 'Orexin AND Sanofi-Aventis' resulted in the following hits, describing orexin receptor antagonistic compounds from the classes depicted in Fig. 3.

The orexin receptor antagonists belonging to Sanofi-Aventis can be divided into two groups. The first group, the sulfonamides, is represented by 20, 21 and 22. ${ }^{[33-35]}$ The compounds represent $\mathrm{OX}_{2}$ selective antagonists with $\mathrm{IC}_{50}$ values of $37 \mathrm{nM}\left(\mathrm{OX}_{2}\right)$ for $\mathbf{2 0}, 9$ $\mathrm{nM}\left(\mathrm{OX}_{2}\right)$ and $103 \mathrm{nM}\left(\mathrm{OX}_{1}\right)$ for 21 , and 9 $\mathrm{nM}\left(\mathrm{OX}_{2}\right)$ and $1870 \mathrm{nM}\left(\mathrm{OX}_{1}\right)$ for 22 . The structures from all three patent applications only differ in the non-aromatic substituent connected to the sulfonamide $\mathrm{N}$-atom. The aromatic substituents from all three groups of antagonists allow the same possibilities and variations. In addition to the sulfonamides, 23 represents a pyrimidine-based orexin receptor antagonist.[36] No hints to activities were disclosed for any representative of this class. Compound 24, a pyrazole based, moderately potent dual orexin receptor antagonist $\left(\mathrm{IC}_{50}(\mathrm{OX} 1)=33 \mathrm{nM} ; \mathrm{IC}_{50}(\mathrm{OX} 2)=156\right.$ $\mathrm{nM})$ is an example from a patent application describing either orexin-1-selective or dual orexin receptor antagonists. ${ }^{[37]}$

\subsection{Orexin Receptor Antagonists from GlaxoSmithKline}

A search in the Integrity ${ }^{\circledR}$ database (Prous Science) in the patents section, with the keywords 'Orexin AND Glaxo' resulted in the following hits, describing compounds from the antagonist classes depicted in Fig. 4. 
GSK holds a large group of patents describing potent, dual orexin receptor antagonists. Many of the compounds are based on 2-aminomethyl-aza-cycloalkanes such as 2-aminomethyl-piperidine, -pyrrolidine, piperazine, -morpholine, -tetrahydroisoquinoline, or tetrahydroquinoline. ${ }^{[38-49]}$ The vast majority of the GSK-compounds contains a 5-aryl-thiazole- or $o$-biphenylor another structurally similar substituent connected to the ring- $\mathrm{N}$-atom via an amide bond. Substituents at the exocyclic $\mathrm{N}$-atom may be of benzamide type or heteroarylamine type forming a 2-amino-pyridine or a 2-amino-pyrimidine subunit. Compound 25 is specifically claimed in a patent application and some of its pharmacological effects are described below in comparison to almorexant (11). Derivatives 26 and 27 are structurally closely related to $\mathbf{2 5}$. In $\mathbf{2 6}$ the central 2-aminomethylpiperidine is replaced by a 4-methyl-2-aminomethylpiperazine. In addition to this change, in 27, the exocyclic benzofuranoyl-unit is replaced by a substituted pyridine group in order to replace one of the amide groups with a heteroaryl moiety. Another group of structurally related orexin receptor antagonists are summarized by $\mathbf{2 8}$, a 3-aminomethyltetrahydroisoquinoline derivative. In addition, this example shows a further possible replacement of the exocyclic benzoyl substituent by a 5-bromo-2-pyrimidin-2-yl unit. Further changes not only in the exocyclic substituent but also in the 5-aryl-thiazole-group are possible as demonstrated with the benzimidazole derivative $\mathbf{2 9}$, the oxadiazole derivative 30, or the aryl ether 31. Compounds 29 (4-aryl-pyrazole-unit) and 30 (o-biphenyl-unit) as well indicate possible variations and replacement options for the formerly almost ubiquitous 5-arylthiazole groups. A different group of orexin receptor antagonists is represented by $\mathbf{3 2}$. This class, according to the statements made in the literature, represents dual and $\mathrm{OX}_{1}$ - or $\mathrm{OX}_{2}$-selective receptor antagonists of astonishingly low structural complexity. With respect to activity the patents disclose average activity ranges of $\mathrm{pKi}$ values from 6.4 to 7.4 (equals $\mathrm{IC}_{50}$ values of approximately 500-50 nM).

\subsection{Miscellaneous Orexin Receptor Antagonists}

Formula 33 (Fig. 5) represents an example of an orexin receptor antagonist from Biovitrum AB. The compounds are described as dual $\mathrm{OX}_{1} / \mathrm{OX}_{2}$-receptor antagonists. ${ }^{[50]}$ Activities indicated as $\mathrm{IC}_{50}$ values are between $30 \mathrm{nM}$ and $2 \mu \mathrm{M}$. Compound 34 is described as a selective $\mathrm{OX}_{2}$-receptor antagonist with a pKi value of 8.3 at the $\mathrm{OX}_{2}$-receptor and a selectivity factor of 600 . $[51,52]$ The last compound depicted in Fig. 5, 35, is a representative from an early class of $\mathrm{OX}_{1}$ selective receptor antagonists. ${ }^{[53,54]}$

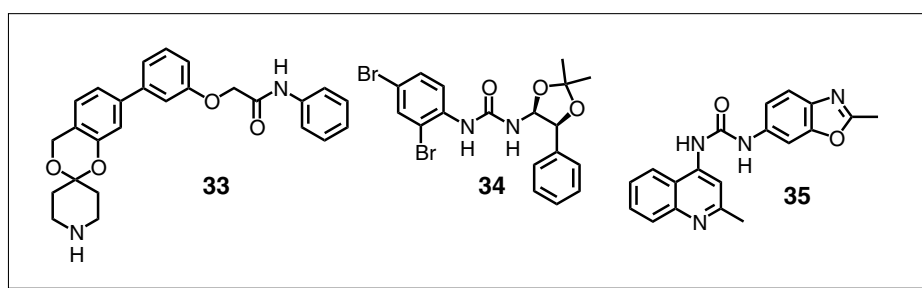

Fig. 5. Miscellaneous structures of orexin receptor antagonists

$\mathrm{OX}_{1}$ selective antagonists are said to decrease food intake in rats with a high fat diet after i.p. administration. ${ }^{[55]}$ Other reports from the scientific literature speculate about the importance of the orexin system with respect to memory acquisition and consolidation again in combination with the $\mathrm{OX}_{1}$ selective antagonist 35. ${ }^{[56]}$ Regarding the clinical potential of either type of selective or dual orexin receptor antagonists, with the exception of insomnia, we can only speculate at the moment. Future clinical trials will hopefully deliver answers.

\section{Biological and Pharmacological Effects of Two Orexin Receptor Antagonists}

Effects of two orexin receptor antagonists with good systemic and brain bioavailability were investigated on sleep and wake cycles in rats: almorexant $\mathbf{( 1 1}$, ACT078573) developed by Actelion Pharmaceuticals Ltd. and compound $\mathbf{2 5}$ taken from a GlaxoSmithKline patent application.

Almorexant (11) is a competitive orexin receptor antagonist active on both human $\mathrm{OX}_{1}$ and $\mathrm{OX}_{2}$ receptors. ${ }^{[7]}$ It inhibited the intracellular $\mathrm{Ca}^{2+}$ increase induced by 10 $\mathrm{nM}$ human orexin-A in Chinese hamster ovary cells overexpressing human $\mathrm{OX}_{1}$ and $\mathrm{OX}_{2}$ receptors. The concentrations of almorexant necessary to inhibit $50 \%$ of the response $\left(\mathrm{IC}_{50}\right)$ for the $\mathrm{OX}_{1}$ receptor were $13 \pm 1 \mathrm{nM}(\mathrm{n}=8)$ and $8 \pm 1 \mathrm{nM}(\mathrm{n}=8)$ for the $\mathrm{OX}_{2}$ receptor. It was more than 600 -fold selective for orexin receptors when tested in 89 receptor-binding or enzyme activity assays including hepatic enzymes.

Compound 25 is also a dual $\mathrm{OX}_{1}$ and $\mathrm{OX}_{2}$ receptor antagonist. The $\mathrm{IC}_{50}$ of this compound measured under the same conditions as almorexant (11) were $2 \pm 0.2 \mathrm{nM}$ $(\mathrm{n}=8)$ and $2.7 \pm 0.4 \mathrm{nM}(\mathrm{n}=8)$ for the $\mathrm{OX}_{1}$ and $\mathrm{OX}_{2}$ human receptors, respectively.

Both almorexant (11) and compound 25 cross the blood-brain-barrier (brain/plasma ratio between 33 and $57 \%$, respectively) (Table 1).

Both compounds present the same pattern of activity on electrophysiological measures of sleep parameters made in freely moving Wistar rats implanted with miniature radiotelemetric probes over several 12-h light-dark cycles.

When given orally at the beginning of the active dark phase in the rat (when intracerebral orexin levels are high), dual orexin receptor antagonists increase the time spent in REM (rapid-eye-movement) and non-REM sleep and decrease the time spent in home cage activity and active wake in a dose-dependent manner (Fig. 6 and 7, $10-300 \mathrm{mg} / \mathrm{kg}$ p.o.). At approximately bioequivalent dose $(100 \mathrm{mg} / \mathrm{kg}$ for almorexant (11) and $30 \mathrm{mg} / \mathrm{kg}$ for compound 25), home cage activity measured over the $12 \mathrm{~h}$ night period, is decreased by $52 \%$ and $55 \%$ (Fig. 6) and active wake by $25 \%$ and $23 \%$ for almorexant (11) and compound 25, respectively (Fig. 7). Total sleep time, over the $12 \mathrm{~h}$ night period, was increased by $27 \%$ for almorexant (11) and $26 \%$ for compound 25 . These results correspond to a non-REM sleep increase of $25 \%$ and $23 \%$

Table 1. Brain and systemic concentration measured 3 and 6 hours following oral administration of $\mathrm{OX}_{1} / \mathrm{OX}_{2}$ receptor antagonists to male Wistar rats

$\begin{array}{ccc}\begin{array}{c}\text { Plasma concentration } \\ {[\mathrm{ng} / \mathrm{ml}]}\end{array} & \begin{array}{c}\text { Brain concentration } \\ {[\mathrm{ng} / \mathrm{g}]}\end{array} & \text { Brain/plasma ratio } \\ & {[\%]}\end{array}$

$100 \mathrm{mg} / \mathrm{kg}$

almorexant $11(n=8)$

\begin{tabular}{|c|c|c|}
\hline 3 hours & $3088 \pm 463$ & $1009 \pm 194$ \\
\hline 6 hours & $2598 \pm 319$ & $864 \pm 174$ \\
\hline
\end{tabular}

$30 \mathrm{mg} / \mathrm{kg}$

Compound $25(n=3)$

$\begin{array}{lll}3 \text { hours } & 1846 \pm 999 & 1055 \pm 427\end{array}$

6 hours $\quad 2115 \pm 593 \quad 944 \pm 287 \quad 45 \%$ 


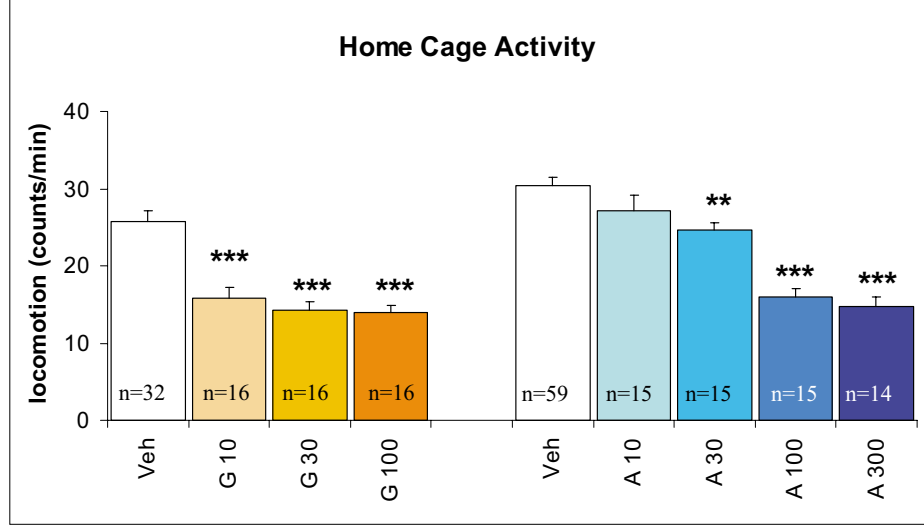

Fig. 6. Dose response for the effects of $\mathrm{OX}_{1} / \mathrm{OX}_{2}$ receptor antagonists (almorexant (11) or $A$ and compound $\mathbf{2 5}$ or $\mathrm{G}$ ) on home cage activity. Data are represented as mean $+/$ - s.e.m. ${ }^{*} p<0.05,{ }^{* \star} p<0.01,{ }^{\star \star \star} p<0.001$.

and a REM sleep increase of $46 \%$ and $39 \%$ for almorexant (11) and compound 25, respectively.

A unique characteristic of these dual $\mathrm{OX}_{1} / \mathrm{OX}_{2}$ receptor antagonists is that the relative proportion of time spent in nonREM and REM sleep over the total sleep time in the $12 \mathrm{~h}$ night period remains unchanged (Table 2).

\section{Discussion and Perspective}

When transient reduction of orexin function was induced by dual orexin receptor antagonists such as almorexant and compound 25, decreased alertness was observed dosedependently in rats. Dual orexin receptor antagonists appear to mimic a physiological state of sleep that occurs when orexin release is decreased during the sleep phase. The maintenance of a natural sleep architecture differs from what is usually seen with $\mathrm{GABA}_{\mathrm{A}}$ receptor modulators such as zolpidem that decrease REM sleep.

Immunoreactivity for orexin A shows diurnal variations in areas of the brain involved in the regulation of sleep, arousal and circadian hormone release. For example, hypothalamic orexin A concentrations are significantly higher during active waking than during slow-wave sleep. This has been observed in cats and rats and extends to humans. Current hypotheses on the role of orexins in the CNS sleep system are influenced by the findings that many different types of neurons, including noradrenergic, serotonergic, histaminergic, glutamatergic and cholinergic neurons (in e.g. basal forebrain, perifornical hypothalamus, locus coeruleus) are strongly innervated by orexin neurons originating in the hypothalamus. This indicates a potentially prominent role of orexins in sleep-wake regulation within certain brain structures. Hypothalamic neurons are under the control of incoming circadian signals from suprachiasmatic nuclei

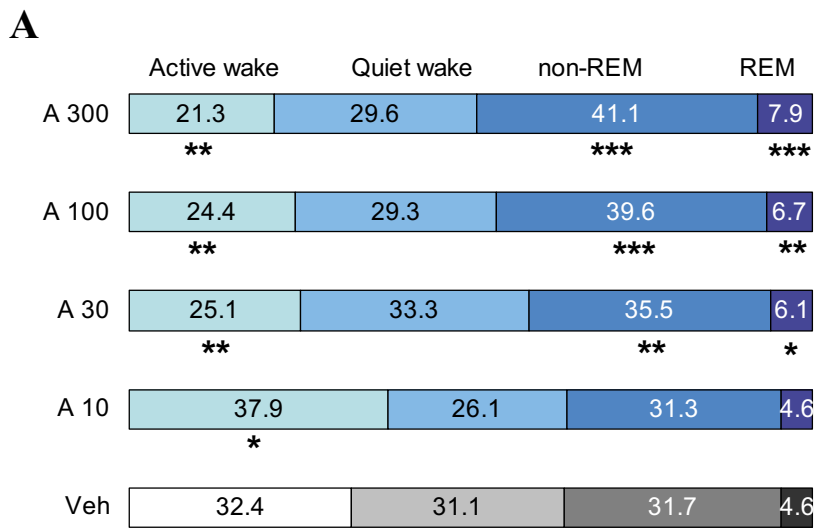

B

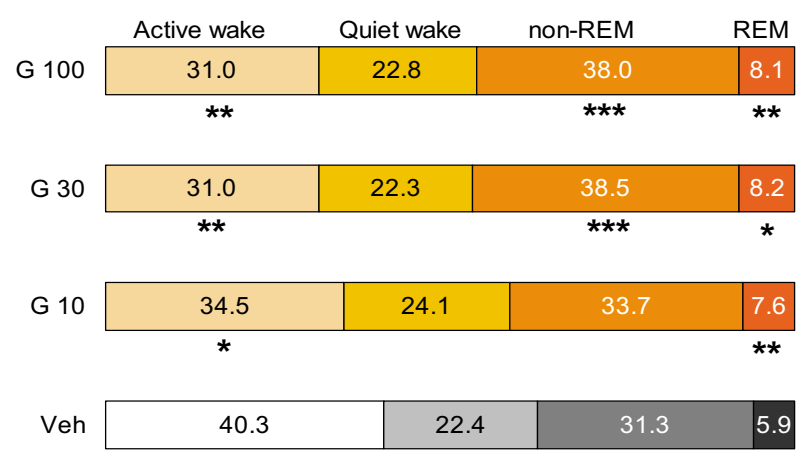

Fig. 7. Values represent the percentage of time spent in each sleep or wake stage over the $12 \mathrm{~h}$ night period following administration, $\mathrm{n}=15$ for $\mathrm{A} 10$ A 30, A 100; $n=14$ for A 300; $n=59$ for Veh in A panel; $n=16$ for $G 10, G$ $30, n=14$ for $G 100 ; n=31$ for Veh in panel $B .{ }^{*} p<0.05,{ }^{\star \star} p<0.01,{ }^{\star \star \star} p$ $<0.001 . A=$ almorexant (11); $G=$ compound 25

Table 2. Proportion of non-REM and REM sleep over the total sleep time of the $12 \mathrm{~h}$ night period.

$\%$ of total sleep time

time spent in non-REM sleep

time in REM sleep

veh / almorexant (11)

$87 \% / 86 \%$

$13 \% / 14 \%$

veh / compound 25

$84 \% / 82 \%$

$16 \% / 18 \%$ (biological clock). Sleep disorders such as primary insomnia are thus possibly related to dysfunctions of the orexin system; this has been recently confirmed in a phase II clinical trial using almorexant (11) in primary insomnia patients. ${ }^{[57]}$

Since the full pathophysiology and clinical pictures of orexin dysfunctions is largely unknown, the possibility for therapeutic opportunities in human or veterinary medicine remains largely open. The relative contributions of $\mathrm{OX}_{1}$ versus $\mathrm{OX}_{2}$ receptors to diverse neurobiological effects and their brain distribution suggests that different physiological effects might be expected from drugs acting in the brain selectively at either $\mathrm{OX}_{1}$ or $\mathrm{OX}_{2}$ receptors or at both receptors in parallel. This will be investigated experimentally using selective and dual orexin antagonists emerging from various medicinal chemistry programs.

\section{Acknowledgements}

The authors would like to thank Cedric Fischer, Helene Roellinger, Julien Hazemann, Jerome Gabillet, Emmanuelle André, Ronny Häner, David Lehmann, Pascal Rebmann, Marc Candreia, Ursula Fusco-Hug, Katalin Menyhart, John Gatfield, Roberto Bravo, and Stephane Delahaye for expert technical support for the synthesis, purification and analysis of compounds as well as the realization of biological and pharmacological experiments, and Henri Ramuz, Martine Clozel and Walter Fischli for stimulating and helpful discussions.

Received: June 30, 2008

[1] T. Sakurai, A. Amemiya, M. Ishii, I. Matsuzaki, R. M. Chemelli, H. Tanaka,S. C. Williams, J. A. Richardson, G. P. Kozlowski, S. Wilson, J. R. Arch, R. E. Buckingham, A. C. Haynes, S. A. Carr, R. S. Annan, D. E. McNulty, W. S. Liu, J. A. 
Terrett, N. A. Elshourbagy, D. J. Bergsma, M. Yanagisawa, Cell 1998, 92, 573.

[2] L. de Lecea, T. S. Kilduff, C. Peyron, X. Gao, P. E. Foye, P. E. Danielson, C. Fukuhara, E. L. Battenberg, V. Gautvik, F. S. Bartlett, W. N. Frankel, A. N. van den Pol, F. E. Bloom, K. M. Gautvik, J. G. Sutcliffe, Proc. Natl. Acad. Sci. USA 1998, 95, 322

[3] A. N. van den Pol, X. B. Gao, K. Obrietan, T. S. Kilduff, A. B. Belousov, J. Neurosci. 1998, 18,7962

[4] A. Ivanov, G. Aston-Jones, Neuroreport 2000, 11, 1755.

[5] K. S. Eriksson, O. Sergeeva, R. E. Brown, H. L. Haas, J. Neurosci. 2001, 21, 9273.

[6] T. Sakurai, T. Moriguchi, K. Furuya, N. Kajiwara, T. Nakamura, M. Yanagisawa, K. Goto, J. Biol. Chem. 1999, 274, 17771.

[7] C. Brisbare-Roch, J. Dingemanse, R Koberstein, P. Hoever, H. Aissaoui, S. Flores, C. Mueller, O. Nayler, J. van Gerven, S. L. de Haas, P. Hess, C. Qiu, S. Buchmann, M. Scherz, T. Weller, W. Fischli, M. Clozel, F. Jenck, Nat. Med. 2007, 13, 150

[8] J. Chen, H. S. Randeva, Mol. Endocrinol. 2004, 18, 2790.

[9] S. Taheri, S. Bloom, Clin. Endocrinol. (Oxf) 2001, 54, 421.

[10] C. Peyron, D. K. Tighe, A. N. van den Pol, L. de Lecea, H. C. Heller, J. G. Sutcliffe, T. S. Kilduff, J. Neurosci. 1998, 18, 9996.

[11] J. J. Hagan, R. A. Leslie, S. Patel, M. L. Evans, T. A. Wattam, S. Holmes, C. D. Benham, S. G. Taylor, C. Routledge, P. Hemmati, R. P. Munton, T. E. Ashmeade, A. S. Shah, J. P. Hatcher, P. D. Hatcher, D. N. Jones, M. I. Smith, D. C. Piper, A. J. Hunter, R. A. Porter, N. Upton, Proc. Natl. Acad. Sci. USA 1999, 96, 10911.

[12] D. C. Piper, N. Upton, M. I. Smith, A. J. Hunter, Eur. J. Neurosci. 2000, 12, 726.

[13] P. J. Coleman, J. D. Schreier, WO Patent Appl. No. WO2006110626, 2006.

[14] P. J. Coleman, J. D. Schreier, WO Patent Appl. No. WO2007126934, 2007.

[15] K. M. Brashear, P. J. Coleman, C. D. Cox, A. M. Smith, D. B. Whitman, WO Patent Appl. No. WO2007126935, 2007.

[16] D. C. Cox, M. J. Breslin, P. J. Coleman, WO Patent Appl. No. WO2008008518, 2008.

[17] P. J. Coleman, C. D. Cox, G. B. McGaughey, A. J. Roecker, J. D. Schreier, WO Patent Appl. No. WO2008008517, 2008.

[18] M. J. Breslin, C. D. Cox, D. B. Whitman, WO Patent Appl. No. WO2007025069, 2007.

[19] J. M. Bergman, P. J. Coleman, C. Cox, G. D. Hartman, C. Lindsley, S. P. Mercer, A. J. Roecker, D. B. Whitman, WO Patent Appl. No. WO 2006127550, 2006.

[20] J. M. Bergman, A. J. Roecker, S. P. Mercer, R. A. Bednar, D. R. Reiss, R. W. Ransom, C. Meacham Harrell, D. J. Pettibone, W. Lemaire, K. L. Murphy, C. Li, T. Prueksaritanont, C. J. Winrow, J. J. Renger, K. S. Koblan, G. D. Hartman, P. J. Coleman, Bioorg. Med. Chem. Lett. 2008, 18,1425 .
[21] C. D. Cox, D. B. Whitman, M. J. Breslin, WO Patent Appl. No. WO2008008551, 2008.

[22] P. J. Coleman, A. J. Roecker, J. M. Bergman, WO Patent Appl. No. WO 2007061763, 2007.

[23] C. D. Cox, P. J. Coleman, D. B. Whitman, WO Patent Appl. No. WO2007019234, 2007.

[24] T. Weller, R. Koberstein, H. Aissaoui, M. Clozel, W. Fischli, WO Patent Appl. No. WO2005118548, 2005

[25] R. Koberstein, H. Aissaoui, D. Bur, M. Clozel, W. Fischli, F. Jenck, C. Mueller, O Nayler, T. Sifferlen, A. Treiber, T. Weller, Chimia 2003, 57, 270.

[26] H. Aissaoui, M. Clozel, T. Weller, R. Koberstein, T. Sifferlen, W. Fischli, WO Patent Appl. No. WO2004085403, 2004.

[27] H. Aissaoui, C. Boss, M. Gude, R. Koberstein, T. Sifferlen, WO Patent Appl. No. WO2007122591, 2007.

[28] H. Aissaoui, M. Clozel, T. Weller, R. Koberstein, T. Sifferlen, W. Fischli, WO Patent Appl. No. WO2002051838, 2002.

[29] H. Aissaoui, M. Clozel, T. Weller, R. Koberstein, T. Sifferlen, W. Fischli, WO Patent Appl. No. WO2004096780, 2004.

[30] H. Aissaoui, M. Clozel, W. Fischli, R. Koberstein, T. Sifferlen, T. Weller, WO Patent Appl. No. WO2004004733, 2004.

[31] H. Aissaoui, C. Boss, M. Gude, R Koberstein, T. Sifferlen, C. Zumbrunn Acklin, WO Patent Appl. No. WO2007116374, 2007.

[32] H. Aissaoui, M. Clozel, T. Weller, R. Koberstein, T. Sifferlen, W. Fischli, WO Patent Appl. No. WO2004033418, 2004.

[33] G. Courtemanche, P. Despeyroux, E. Fontaine, P. Rochard, C. Serradeil-Le Gal, E. v. Roederen, WO Patent Appl. No. WO2007088276, 2007.

[34] P. Courtemanche, E. Fontaine, P. Despeyroux, P. Rochard, C. Serradeil-Le Gal,WOPatentAppl.No.WO2007085718, 2007.

[35] G. Courtemanche, P. Despeyroux, E. Fontaine, P. Rochard, C. Serradeil-Le Gal, WO Patent Appl. No. WO2006024779, 2006.

[36] P. Aranyi, M. Balogh, S. Batori, J. Bence, M. Finet, Z. Kapul, C. Philippo, T. Szabo, Z. Szlavik, Z. Tömösközi, K. UrbanSzabo, O. Venier, WO Patent Appl. No. WO2005075458, 2005.

[37] M. Aletru, P. Aranyi, M. Balogh, S. Batori, J. Bence, P. Bovy, Z. Kapui, E. Mikus, C. Namane, C. Philippo, T. Szabo, Z. Tömösközi, K. Urban-Szabo, WO Patent Appl. No. WO2005060959, 2005.

[38] C. L. Branch, C. N. Johnson, G. Stemp, K. Thewlis, EP Patent Appl. No. EP1289955, 2001.

[39] C. L. Branch, C. N. Johnson, D. J. Nash, G. Stemp, WO Patent Appl. No. WO2003041711, 2003

[40] C. L. Branch, S. Coulton, D. J. Nash, A. R. Porter, WO Patent Appl. No. WO2003051873, 2003.

[41] S. Coulton, R. A. Porter, WO Patent Appl. No. WO2004041807, 2004.
[42] W. N. Chan, D. J. Nash, R. A. Porter, R. E. A. Stead, WO Patent Appl. No. WO2004041791, 2004.

[43] C. L. Branch, S. Coulton, A. Johns, D. J. Nash, R. A. Porter, G. Stemp, WO Patent Appl. No. WO2004026866, 2004.

[44] C. L. Branch, J.-P. Pilleux, R. A. Porter, WO Patent Appl. No. WO2004041816, 2004.

[45] C. L. Branch, D. J. Nash, G. Stemp, WO Patent Appl. No. WO2003051368, 2003.

[46] C. L. Branch, W. N. Chan, A. Johns, C. N. Johnson, D. J. Nash, R. Novelli, J.-P. Pilleux, R. A. Porter, R. E. A. Stead, G. Stemp, WO Patent Appl. No. WO2003002561, 2003

[47] W. N. Chan, A. Johns, C. N. Johnson, R. Novelli, R. A. Porter, WO Patent Appl. No. WO2003002559, 2003.

[48] C. L. Branch, C. N. Johnson, D. J. Nash, G. Stemp, WO Patent Appl. No. WO2003032991, 2003.

[49] W. N. Chan, A. Johns, R. A. Porter, R. W. A. Stead, M. Vimal, WO Patent Appl. No. WO2003037847, 2003.

[50] E. Barker, A. Jenmalm Jensen, E. Nordling, A. Proud, M. Slater, M. Weber, WO Patent Appl. No. WO2006067224, 2006.

[51] N. I. Carruthers, T. K. Jones, X. Li, T. W. Lovenberg, L. C. McAtee, V. K. Phuong, D. A. Rudolph, S. W. Johnson, WO Patent Appl. No. WO2004052876, 2004.

[52] L. C. McAtee, S. W. Sutton, D. A Rudolph, X. Li, L. E. Aluisio, V. K. Phuong, C. A. Dvorak, T. W. Lovenberg, N. I. Carruthers, T. K. Jones, Bioorg. Med. Chem. Lett. 2004, 14, 4225.

[53] A. Johns, R. A. Porter, WO Patent Appl. No. WO199958533, 1999.

[54] S. Coulton, A. Johns, R. A. Porter, WO Patent Appl. No. WO200047577, 2000.

[55] C. L. White, Y. Ishii, T. Mendoza, N. Upton, L. P. Stasi, G. A. Bray, D. A. York, Peptides 2005, 26, 2331.

[56] E. Akbari, N. Naghdi, F. Motamedi, Peptides 2007, 28, 650.

[57] J. Dingemanse, G. Dorffner, H. Göran, H. Benes, H. Danker-Hopfe, O. Polo, B. Saletu, M. Barbanoj, G. Pillar, Sleep and Biological Rhythms 2007, 5, A-194. 